International Journal of Current Micro6iology and Applied Sciences

ISSN: 2319-7706 Volume 8 Number 10 (2019)

Journal homepage: http://www.ijcmas.com

\title{
Molecular Characterization of Major Types of Staphylococcal Cassette Chromosome mec (SCCmec) in Methicillin-Resistant Staphylococci (MRS) from Animal and Human Origin
}

\author{
S.N. Ghodasara ${ }^{1}$, J.H. Purohit ${ }^{2}$, A.R. Baria ${ }^{3}$, A.S. Patel ${ }^{3}$, B.B. Javia ${ }^{1}$, \\ D.B. Barad ${ }^{1}$, J.A. Kathiria ${ }^{4}$ and A.R. Bhadania ${ }^{5}$ \\ ${ }^{1}$ Department of Veterinary Microbiology, College of Veterinary Science and A. H., Junagadh \\ Agricultural University, Junagadh, Gujarat, India \\ ${ }^{2}$ Department of Veterinary Microbiology, College of Veterinary Science and A. H., Anand \\ Agricultural University, Anand, Gujarat, India \\ ${ }^{3}$ Department of Livestock Products Technology, College of Veterinary Science and A. H., \\ Junagadh Agricultural University, Junagadh, Gujarat, India \\ ${ }^{4}$ Department of Veterinary Public Health and Epidemiology, College of Veterinary Science \\ and A. H., Junagadh Agricultural University, Junagadh, Gujarat, India \\ ${ }^{5}$ Department of Veterinary Pathology, College of Veterinary Science and A. H., Junagadh \\ Agricultural University, Junagadh, Gujarat, India \\ *Corresponding author
}

\section{Keywords \\ SCCmec, \\ Methicillin, \\ Community \\ associated, Hospital associated, Nasal swab}

Article Info

Accepted:

10 September 2019

Available Online:

10 October 2019
A B S T R A C T

A total of 202 animal samples (167 milk and 35 pus/exudate samples from cattle and buffalo) were collected and examined from dairy cattle and buffaloes. Simultaneously, 100 nasal swabs were collected from the closely associated personnel and farm workers. Out of these, the Staphylococcus spp. were isolated from86 (42.57\%) animal and 62 (62\%) human samples. Of these, total 9 isolates from animals and 20 isolates from human were identified as MRS positive. Out of 9 and 20 MRS isolates from animal and human, 1 $(11.11 \%)$ and 2 (10\%) isolate were Methicillin-Resistant Coagulase Positive Staphylococcus (MRCoPS), whereas 8 (88.89\%) and 18 (90\%) isolates were MethicillinResistant Coagulase Negative Staphylococcus (MRCoNS), respectively. The SCCmec typing of 16 and 40 MRS (Including departmental isolates) isolates from animal and human were carried out. Out of these, the study revealed $18.75 \%(3 / 16)$ and $25 \%(10 / 40)$ isolates were classified as hospital associated methicillin-resistant staphylococci (HAMRS), whereas $68.75 \%(11 / 16)$ and $45 \%$ (18/40) isolates were classified as community associated methicillin resistant staphylococci (CA-MRS) and $12.5 \%(2 / 16)$ and $30 \%$ (12/40) MRS isolates remained untypable, respectively. The overall percentage of CAMRS (63.04\%) was higher as compare to HA-MRS (28.26\%) among both the species. 


\section{Introduction}

Staphylococcus aureus is one of the most extensively studied bacteria of genus Staphylococcus. During recent years, Coagulase Negative Staphylococci (CNS) referred as "Environmental Staphs" have become the most common bovine mastitis isolates in many countries and are regarded as emerging mastitis pathogens (Jakee et al., 2013).

Amongst the Staphylococci group, Staphylococcus aureus strains are more dangerous to dairy animals and are of greatest attention for scientific community worldwide as they have ability to resist antibiotic therapy due to production of beta-lactamases a group of enzymes that inactivate penicillin and closely related antibiotics. To overcome infections caused by beta-lactamase producing Staphylococci, narrow spectrum semisynthetic penicillin (methicillin) was introduced. However, soon after introduction, Methicillin-resistant Staphylococcus aureus (MRSA) strain was identified. Initially, MRSA strains were encountered only in the hospitals, but in the late 1990s first virulent community-acquired MRSA (CA-MRSA) clones, characterized by the presence of the toxin Panton-Valentine Leukocidin $(P V L)$, appeared rapidly and unexpectedly. They quickly spread worldwide, initially only in the community, but later on also in the healthcare facilities, displacing in some countries typical HA-MRSA. For this reason, nowadays, distinction between CA-MRSA and mostly multi resistant HA-MRSA become challenging (Chambers and Deleo, 2009).

MRSA needs to be identified below the species level by rapid and reliable typing methods. Staphylococcal cassette chromosome mec (SCCmec) typing accompanied with overall genotyping has already provided strong evidence for the independent origins of healthcare associated MRSA and community acquired MRSA (Naimi et al., 2003). To date, eleven different types of SCCmec (I-XI) have been defined on the basis of the combination of $c c r$ and mec complexes, but only type I-V are globally distributed, while others appear to exist as local strains in the country of origin (Zhang et al., 2009). Among this five types, SCCmec types I, II and III are mainly associated with healthcare associated MRSA (HA-MRSA) strains, whereas SCCmec type IV and Vare associated with community associated MRSA (CA-MRSA) strains, as well as with the Pediatric clone MRSA strains (Shore et al., 2005).

The literature reviewed that there are lots of reports on staphylococcal cassette chromosome mec (SCCmec) types in Methicillin-resistance Staphylococci of human origin across the globe including India, but in compare to human, few reports on SCCmec typing have been published from animals across the globe and still very few from India. The identification and molecular SCCmec typing and epidemiological studies have been conducted from pig and human, but scanty of references available regarding animal and human SCCmec types, epidemiological studies and their relationship in the world and in India.

\section{Materials and Methods}

The present investigation was carried out to optimize and standardize uniplex PCR for various types of Staphylococci SCCmec types from MRS prevalent in this region in animals and closely associated human beings that will facilitate the study of epidemiological correlation between human and animal isolates on the basis of hospital acquired methicillin resistance staphylococci (HAMRS) or community acquire methicillin resistance staphylococci (CA-MRS). 
Collection of samples from milk, pus/exudate (abscess) from animal and human nasal swabs

A total of 202 animal samples (167 milk and 35 pus/exudate samples from cattle and buffalo) were collected and examined from dairy cattle and buffaloes. Simultaneously, 100 nasal swabs were collected from the closely associated personnel and farm workers aseptically as per the guidelines given by Peacock et al., (2001). The milk samples were collected from clinical and sub clinical mastitis as per the guidelines laid by European Food Safety Authority (EFSA, 2009). Simultaneously, the isolates of Staphylococci previously recovered from subclinical and clinical mastitic milk from bovines and human nasal swabs and maintained at the Department of Veterinary Microbiology, Junagadh Agricultural University, were included in the study for SCCmec typing.

The isolates presumably identified as Staphylococcus spp. based on cultural, colony and biochemical characteristics (Result not shown) and amplified with different pairs of 4 primers by $\mathrm{m}$-PCR for the identification of Methicillin-Resistance coagulase positive staphylococci (MRCoPS) or MethicillinResistance coagulase negative staphylococci (MRCoNS).

The isolates were confirmed as methicillin resistant staphylococci (MRS) using mecApositive gene amplification. The isolates confirmed as MRS were further subjected to SCCmec typing using four primer-pairs designed to identify the five main known SCCmec types.

Isolation of bacterial genomic DNA from bacterial culture by Proteinase K-SDS method

The genomic DNA of staphylococci from bacterial broth culture was extracted according to Parayre et al., (2007) with minor modifications.

\section{Molecular detection of MRSA isolates from animal and humans}

Four predominant genes (16S rRNA, Nuc, Coa \& MecA gene targets) (Table 1) identified based on the outcome of phenotype-based speciation were considered to be included for detection by m-PCR. From all genes, $16 \mathrm{~S}$ $r R N A$ was used to identify genus i.e. Staphylococci, Nuc gene encodes for thermonuclease was used to identify species i.e. Staphylococcus aureus, Coa gene encodes for coagulase was used as pathogenicity indicator and mecA gene target encodes for modified penicillin binding protein $2 \mathrm{~B}$ was used for genotypically identification of methicillin resistance in Staphylococcus spp. Five microliters of the extracted DNA were used as a template in a25 $\mu \mathrm{L}$ PCR mixture containing $14.25 \mu$ Lof $2 \mathrm{X}$ PCR master mix (Thermoscietific) $(0.05 \mathrm{U} / \mu \mathrm{L}$ Taq DNA polymerase, reaction buffer, $4 \mathrm{mM} \mathrm{MgCl} 2,0.4$ $\mathrm{mM}$ of each dNTP (dATP, dCTP, dGTPand dTTP), $0.5 \mu \mathrm{L}$ of each forward and reverse primer except mecA(1.25 $\mu \mathrm{L}$ of each forward and reverse primers) and $0.1 \quad \mu$ LTaq Polymerase $(5 \mathrm{U} / \mu \mathrm{l})$ (Thermo scientific).

The reference strain of Staphylococcus aureus ATCC 43300 and ATCC 25923 (Himedia Pvt. Ltd., Mumbai) was used as negative and positive control, respectively for mecA gene. The Steps and cycling conditions for m-PCR were Initial denaturation at $94{ }^{\circ} \mathrm{C}$ for $5 \mathrm{~min}$ followed by 40 cycle of Denaturation at $94{ }^{\circ} \mathrm{C}$ for $30 \mathrm{sec}$, Annealing at $52{ }^{\circ} \mathrm{C}$ for $1 \mathrm{~min}$., Extension at $72{ }^{\circ} \mathrm{C}$ for $1 \mathrm{~min}$ and Final extension at $72{ }^{\circ} \mathrm{C}$ for $10 \mathrm{~min}$ in $\mathrm{m}$-PCR. Using m-PCR Methicillin Resistant Coagulase Positive Staphylococci (MRCoPS) as well as Methicillin Resistant Coagulase Negative Staphylococci (MRCoNS) were identified in one single reaction. 
Molecular detection of SCCmec types from methicillin-resistant staphylococci from animal and humans

Four primer sets were used to ensure amplification of two DNA targets from SCCmec type IV and two targets from SCCmec type V. The targets were chosen so that one target would be amplified from each of SCCmec types I-III (Table 2). The PCR of MRS colonies was carried out in final reaction volume of $25 \mu \mathrm{l}$ in thermal cycler (verity, Applied Biosystems by life technology, Singapore).

Three microliters of the extracted DNA were used as a template in a $25 \mu \mathrm{L}$ PCR mixture containing $12.5 \mu \mathrm{L}$ of $2 \mathrm{X}$ PCR master mix (Thermoscientific) $(0.05 \mathrm{U} / \mu \mathrm{L}$ Taq DNA polymerase, reaction buffer, $4 \mathrm{mM} \mathrm{MgCl} 2,0.4$ mM of each dNTP (dATP, dCTP, dGTPand dTTP), $1 \mu \mathrm{L}$ of each forward and reverse primer and $7.5 \mu \mathrm{l}$ nuclease free water.

The Steps and cycling conditions for PCR were Initial denaturation at $94{ }^{\circ} \mathrm{C}$ for $4 \mathrm{~min}$ followed by 30 cycle of Denaturation at $94{ }^{\circ} \mathrm{C}$ for $30 \mathrm{sec}$, Annealing at $55{ }^{\circ} \mathrm{C}$ for $30 \mathrm{sec}$, Extension at $72{ }^{\circ} \mathrm{C}$ for $60 \mathrm{sec}$ and Final extension at $72{ }^{\circ} \mathrm{C}$ for $4 \mathrm{~min}$ for different primer pairs described by Boye et al., (Boye et al., 2007). The reference strain of E. coli (MTCC-522) strain was used as SCCmec types negative.

PCR products $(5 \mu \mathrm{L})$ were analyzed by electrophoresis on agarose $1.5 \% \mathrm{w} / \mathrm{v}$ gel followed by staining with ethidium bromide. The SCCmec type was determined on the basis of the band pattern obtained (Table 3 ).

Isolates with no visible bands, or with a band pattern that was not in agreement with one of the five predicted band patterns, were classified as non typeable (NT).

\section{Results and Discussion}

m-PCR for the detection of MRSA from animal and human isolates

The 202 animal samples (milk, pus/exudate) and 100 human nasal swabs were processed for isolation of bacteria as per standard procedures (Quinn et al., 1994). Out of total 202 animal and 100 human samples collected $86(42.57 \%)$ and 62 (62\%) isolates, respectively were identified as Staphylococcus spp. based on phenotypic, biochemical growth patterns (Result not shown) and molecular characterization.

The m-PCR was carried out for detail classification and characterization of presumably identified staphylococci. Out of total 202 animal samples, 86 isolates were identified as staphylococci based on amplification of $16 \mathrm{~S} r R N A$ gene. Of these, 74 isolates were identified as Coagulase Negative Staphylococci (CoNS) based on amplification of only $16 \mathrm{~S} r R N A$ gene and 12 isolates were identified as Coagulase Positive Staphylococci (CoPS) based on amplification of both $16 \mathrm{~S}$ rRNA and Coa gene. Based on amplification of three genes $16 \mathrm{~S}$ rRNA, Coa and mecA, 8 isolates were identified as Methicillin-resistant Coagulase Negative Staphylococci (MRCoNS) and 1 isolates were MethicillinResistant Coagulase Positive Staphylococci (MRCoPS), whereas only one isolate was identified (based on all four gene amplification pattern) as Methicillin-Resistant Coagulase Negative Staphylococcus aureus (MRCoNSA) from the animal samples (Table 4). Based on amplification of genes $16 S$ rRNA and mecA gene, 9 isolates were identified as positive for Methicillin-Resistant Staphylococci (MRS) (Figure 1).

The 100 samples were collected from the human nasal swabs which had remained in contact with these animals. Of these, 62 
isolates were identified as Staphylococcus based on amplification of $16 S$ rRNA gene and 50 isolates were identified as Coagulase Negative Staphylococci (CoNS) based on amplification of only $16 S \mathrm{rRNA}$ gene and 12 isolates were identified as Coagulase Positive Staphylococci (CoPS) based on amplification of both 16S rRNA and Coa gene. Based on amplification of three genes $16 \mathrm{~S}$ rRNA, Coa and $m e c A, \quad 18$ isolates were identified as Methicillin-Resistant Coagulase Negative Staphylococci (MRCoNS) and 2 isolates were identified as Methicillin-Resistant Coagulase Positive Staphylococci (MRCoPS), whereas only 2 isolates were identified (based on all four gene amplification pattern) as MRSA. Of this 2 isolates, one isolate was MethicillinResistant Coagulase Negative Staphylococcus aureus (MRCoNSA) and one isolate was Methicillin-Resistant Coagulase Positive Staphylococcus aureus (MRCoPSA) from the human samples (Table 4). Based on amplification of genes 16S rRNA and mecA gene, 20 isolates were identified MRS positive.

Molecular characterization of major SCCmec types among MRS from animal and humans

The occurrence of staphylococcal cassette chromosome mec types (SCCmec types) were investigated from MRS isolates obtained from animal and human samples. Out of total 133 and 102 Staphylococcus spp. isolates (47 and 40 departmental staphylococci isolates from animal and human were included, respectively), 16 and 40 isolates from animal and human were identified as Methicillinresistant staphylococci, respectively. Of these 16 animal MRS isolates, 14 isolates having one of the SCCmec types (SCCmec type I, 2; SCCmec type II, 0; SCCmec type III, 1; SCCmec type IV, 5; SCCmec type V, 6), whereas 2 isolates were untypable, whereas from 40 human MRS isolates, 28 isolates having one of the SCCmec types (SCCmec type I, 7; SCCmec type II, 0; SCCmec type III, 3; SCCmec type IV, 9; SCCmec type V, 9), whereas 12 isolates were Untypable (Table 5 and Figure 2).

During the current study, $18.75 \% \quad(3 / 16)$ isolates were classified as hospital associated methicillin-resistant staphylococci (HA-MRS) (SCCmec type I, 2; SCCmec type III, 1), whereas $68.75 \% \quad(11 / 16)$ isolates were classified as community associated methicillin resistant staphylococci (CA-MRS) (SCCmec type IV, 5; SCCmec type V, 6) and $12.5 \%$ $(2 / 16)$ isolates remained untypable from animal MRS isolates.

Table.1 Nucleotide sequences of primers used for m-PCR along with their product size and references

\begin{tabular}{|c|c|c|c|c|}
\hline $\begin{array}{l}\text { Sr. } \\
\text { No. }\end{array}$ & $\begin{array}{l}\text { Name of } \\
\text { primer }\end{array}$ & Primer sequence $\left(5^{\prime}--3^{\prime}\right)$ & $\begin{array}{l}\text { Product } \\
\text { size }\end{array}$ & Reference \\
\hline 1 & $\begin{array}{l}\text { TStaG422F1 } \\
\text { TStaG765R1 }\end{array}$ & $\begin{array}{l}\text { 5'- GGC CGT GTT GAA CGT GGT CAA ATC A-3' } \\
\text { 5'- TIA CCA TTT CAG TAC CTT CTG GTA A-3' }\end{array}$ & 370 bp & $\begin{array}{l}\text { (Martineauet } \\
\text { al., 2001) }\end{array}$ \\
\hline 2 & $\begin{array}{l}\text { Nuc F } \\
\text { Nuc R }\end{array}$ & $\begin{array}{l}5-\text { GCG ATT GAT GGT GAT ACG GT } \\
5 \text { - ACG CAA GCC TTG ACG AAC TA }\end{array}$ & $280 \mathrm{bp}$ & $\begin{array}{l}\text { (Brakstadet } \\
\text { al., 1992) }\end{array}$ \\
\hline 3 & $\begin{array}{l}\text { Coa F1 } \\
\text { Coa R1 }\end{array}$ & $\begin{array}{l}\text { 5'- GTA GAT TGG GCA ATT ACA TTT TGG AGG -3' } \\
\text { 5'- CGC ATC AGC TTT GTT ATC CCA TGT A -3' }\end{array}$ & $117 \mathrm{bp}$ & $\begin{array}{l}\text { (Moon et al., } \\
\text { 2007) }\end{array}$ \\
\hline 4 & $\begin{array}{l}\operatorname{mec} A \mathrm{~F} 1 \\
\operatorname{mec} A \mathrm{R} 1\end{array}$ & $\begin{array}{l}\text { 5'- 'GAGT TGT AGT TGT CGG GTT TGG-3' } \\
\text { 5'- ' GGC CAA TTC CAC ATT GTT TC-3' }\end{array}$ & $454 \mathrm{bp}$ & $\begin{array}{l}\text { (Malik et al., } \\
\text { 2006) }\end{array}$ \\
\hline
\end{tabular}


Table.2 Nucleotide sequences of primers used for the identification of SCCmec types of MRS

\begin{tabular}{|c|c|c|c|c|}
\hline $\begin{array}{l}\text { Sr. } \\
\text { No. }\end{array}$ & $\begin{array}{l}\text { Name of } \\
\text { primer }\end{array}$ & Primer sequence (5'-- 3') & $\begin{array}{l}\text { Product } \\
\text { size }\end{array}$ & Reference \\
\hline 1 & $\begin{array}{l}\beta \text { F1 } \\
\alpha 3 \text { R1 }\end{array}$ & $\begin{array}{l}\text { 5'- ATTGCCTTGATAATAGCCYTCT -3' } \\
\text { 5'- TAAAGGCATCAATGCACAAACACT-3' }\end{array}$ & $937 \mathrm{bp}$ & $\begin{array}{l}\text { (Ito et al., } \\
2001)\end{array}$ \\
\hline 2 & & $\begin{array}{l}5 '-C C \\
5 '-C C\end{array}$ & 518 & $\begin{array}{l}\text { (Ito et al., } \\
2004)\end{array}$ \\
\hline 3 & & $\begin{array}{l}\text { 5'- GCCACTCATAACATATGGAA-3' } \\
\text { 5'- CATCCGAGTGAAACCCAAA-3' }\end{array}$ & 415 & $\begin{array}{l}\text { (Boye et al., } \\
2007)\end{array}$ \\
\hline 4 & mecAF1 & $\begin{array}{l}\text { 5'- TATACCAAACCCGACAACTAC-3' } \\
\text { 5'- CGGCTACAGTGATAACATCC-3' }\end{array}$ & $359 \mathrm{D}$ & $\begin{array}{l}\text { (Boye et al., } \\
\text { 2007) }\end{array}$ \\
\hline
\end{tabular}

Table.3 Primers used in SCCmec typing PCR and the resulting gel band patterns of SCCmec types I-V

\begin{tabular}{|c|c|c|c|c|c|c|c|c|}
\hline \multirow{2}{*}{$\begin{array}{l}\text { Sr. } \\
\text { No. }\end{array}$} & \multirow{2}{*}{$\begin{array}{l}\text { Name of } \\
\text { primer }\end{array}$} & \multirow{2}{*}{$\begin{array}{l}\text { Product } \\
\text { size }\end{array}$} & \multirow{2}{*}{$\begin{array}{c}\text { Target } \\
\text { Gene }\end{array}$} & \multicolumn{5}{|c|}{ SCCmec type } \\
\hline & & & & I & II & III & IV & $\mathbf{V}$ \\
\hline 1 & $\begin{array}{c}\beta \mathrm{F} 1 \\
\alpha 3 \mathrm{R} 1\end{array}$ & 937 bp & $\begin{array}{c}\text { ccrA2- } \\
\text { B }\end{array}$ & & $\sqrt{ }$ & & $\sqrt{ }$ & \\
\hline 2 & $\begin{array}{l}\text { ccrCF1 } \\
\text { ccrCR1 }\end{array}$ & 518 bp & $\operatorname{ccrC}$ & & & $\sqrt{ }$ & & $\sqrt{ }$ \\
\hline 3 & $\begin{array}{l}\text { 1272F1 } \\
1272 \mathrm{R} 1\end{array}$ & 415 bp & IS1272 & $\sqrt{ }$ & & & $\sqrt{ }$ & \\
\hline 4 & $\begin{array}{c}\text { 5RmecAF1 } \\
\text { 5R431R1 }\end{array}$ & 359 bp & $\begin{array}{c}\text { mecA- } \\
\text { IS431 }\end{array}$ & & & & & $\sqrt{ }$ \\
\hline
\end{tabular}

$\sqrt{ }$-Desired amplification of gene.

Table.4 Coagulase Negative (MRCoNS) and coagulase positive (MRCoPS) MRS isolates from animal ad humans

\begin{tabular}{|c|c|c|c|c|c|}
\hline $\begin{array}{c}\text { Sample } \\
\text { origin }\end{array}$ & $\begin{array}{c}\text { No. of } \\
\text { samples } \\
\text { collected }\end{array}$ & $\begin{array}{c}\text { No. of sample } \\
\text { found positive for } \\
\text { Staphylococcus } \\
\text { spp. }\end{array}$ & $\begin{array}{c}\text { Methicillin-Resistant } \\
\text { Staphylococcus } \\
\text { (out of positive } \\
\text { Staphylococcus) }\end{array}$ & \multicolumn{2}{|c|}{$\begin{array}{c}\text { No. (\%) Methicillin- } \\
\text { Resistant } \\
\text { Staphylococcus }\end{array}$} \\
\cline { 5 - 7 } & $\begin{array}{c}\text { MRCoNS } \\
\text { (\%) }\end{array}$ & $\begin{array}{c}\text { MRCoPS } \\
\text { No. (\%) }\end{array}$ & No. (\%) \\
\hline $\begin{array}{c}\text { Animals } \\
\text { (Milk+Pus) }\end{array}$ & 202 & 86 & 9 & 8 & 1 \\
\hline $\begin{array}{c}\text { Human } \\
\text { (Nasal } \\
\text { swabs) }\end{array}$ & 100 & $(42.57)$ & $(10.47)$ & $(88.89)$ & $(11.11)$ \\
\hline
\end{tabular}

MRCoNS - Methicillin-Resistant Coagulase Negative Staphylococcus MRCoPS - Methicillin-Resistant Coagulase Positive Staphylococcus 
Table.5 Occurrence and correlation between SCCmec type isolates based on HA-MRS and CAMRS among animal and human MRS isolates

\begin{tabular}{|c|c|c|c|c|c|c|}
\hline & \multicolumn{3}{|c|}{ MRS isolates from Animal } & \multicolumn{3}{|c|}{ MRS isolates from Human } \\
\hline $\begin{array}{c}\text { SCCmec } \\
\text { types of } \\
\text { MRS }\end{array}$ & $\begin{array}{l}\text { Positive for } \\
\text { SCCmec } \\
\text { type No. } \\
(\%)\end{array}$ & $\begin{array}{c}\text { MRS } \\
\text { type }\end{array}$ & $\begin{array}{c}\text { No. }(\%) \\
\text { Positive } \\
\text { for HA- } \\
\text { MRS/ } \\
\text { CA-MRS }\end{array}$ & $\begin{array}{l}\text { Positive } \\
\text { for } \\
\text { SCCmec } \\
\text { type (No.) }\end{array}$ & $\begin{array}{c}\text { MRS } \\
\text { type }\end{array}$ & $\begin{array}{c}\text { No. }(\%) \\
\text { Positive for } \\
\text { HA-MRS/ } \\
\text { CA-MRS }\end{array}$ \\
\hline $\begin{array}{c}\text { SCCmec } \\
\text { type I }\end{array}$ & $2(12.5)$ & $\begin{array}{l}\text { HA- } \\
\text { MRS }\end{array}$ & \multirow{3}{*}{$3(\mathbf{1 8 . 7 5 )}$} & $7(17.5)$ & $\begin{array}{l}\text { HA- } \\
\text { MRS }\end{array}$ & \multirow{3}{*}{$10(25)$} \\
\hline $\begin{array}{c}\text { SCCmec } \\
\text { type II }\end{array}$ & 0 & - & & 0 & - & \\
\hline $\begin{array}{c}\text { SCCmec } \\
\text { type III }\end{array}$ & $1(6.25)$ & $\begin{array}{l}\text { HA- } \\
\text { MRS }\end{array}$ & & $3(7.5)$ & $\begin{array}{l}\text { HA- } \\
\text { MRS }\end{array}$ & \\
\hline $\begin{array}{c}\text { SCCmec } \\
\text { type IV }\end{array}$ & $5(31.25)$ & $\begin{array}{l}\text { CA- } \\
\text { MRS }\end{array}$ & \multirow[t]{2}{*}{$11(68.75)$} & $9(22.5)$ & $\begin{array}{l}\text { CA- } \\
\text { MRS }\end{array}$ & \multirow[t]{2}{*}{$18(45)$} \\
\hline $\begin{array}{c}\text { SCCmec } \\
\text { type V }\end{array}$ & $6(37.5)$ & $\begin{array}{l}\text { CA- } \\
\text { MRS }\end{array}$ & & $9(22.5)$ & $\begin{array}{l}\text { CA- } \\
\text { MRS }\end{array}$ & \\
\hline UT & $2(12.5)$ & - & $2(12.5)$ & $12(30)$ & - & $12(30)$ \\
\hline Total & 16 & & & 40 & & \\
\hline
\end{tabular}

Figure.1 PCR amplicons of Methicillin-resistant coagulase negative/positive Staphylococcus aureus by mPCR $(16 S r R N A$ gene $=370 \mathrm{bp}$, MecA $=454 \mathrm{bp}$, Coa $=280 \mathrm{bp}$ and $N u c=117 \mathrm{bp})$ from animal isolates

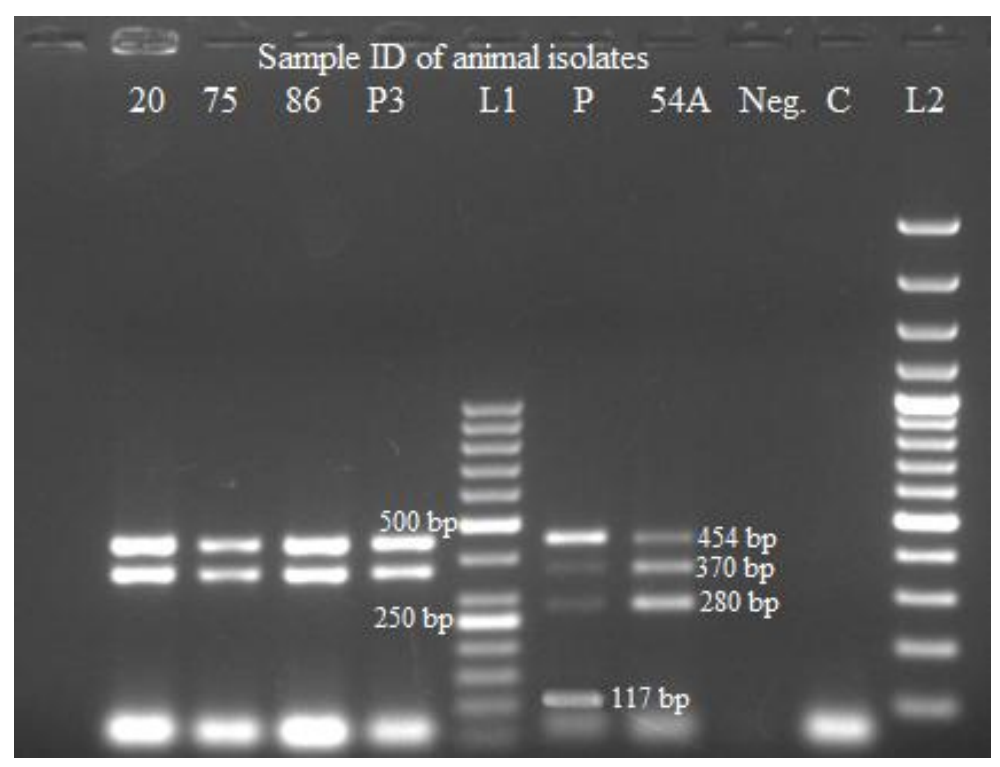


Figure.2 SCCmec type specific PCR amplification products (SCCmec type I-V) from human MRS isolates

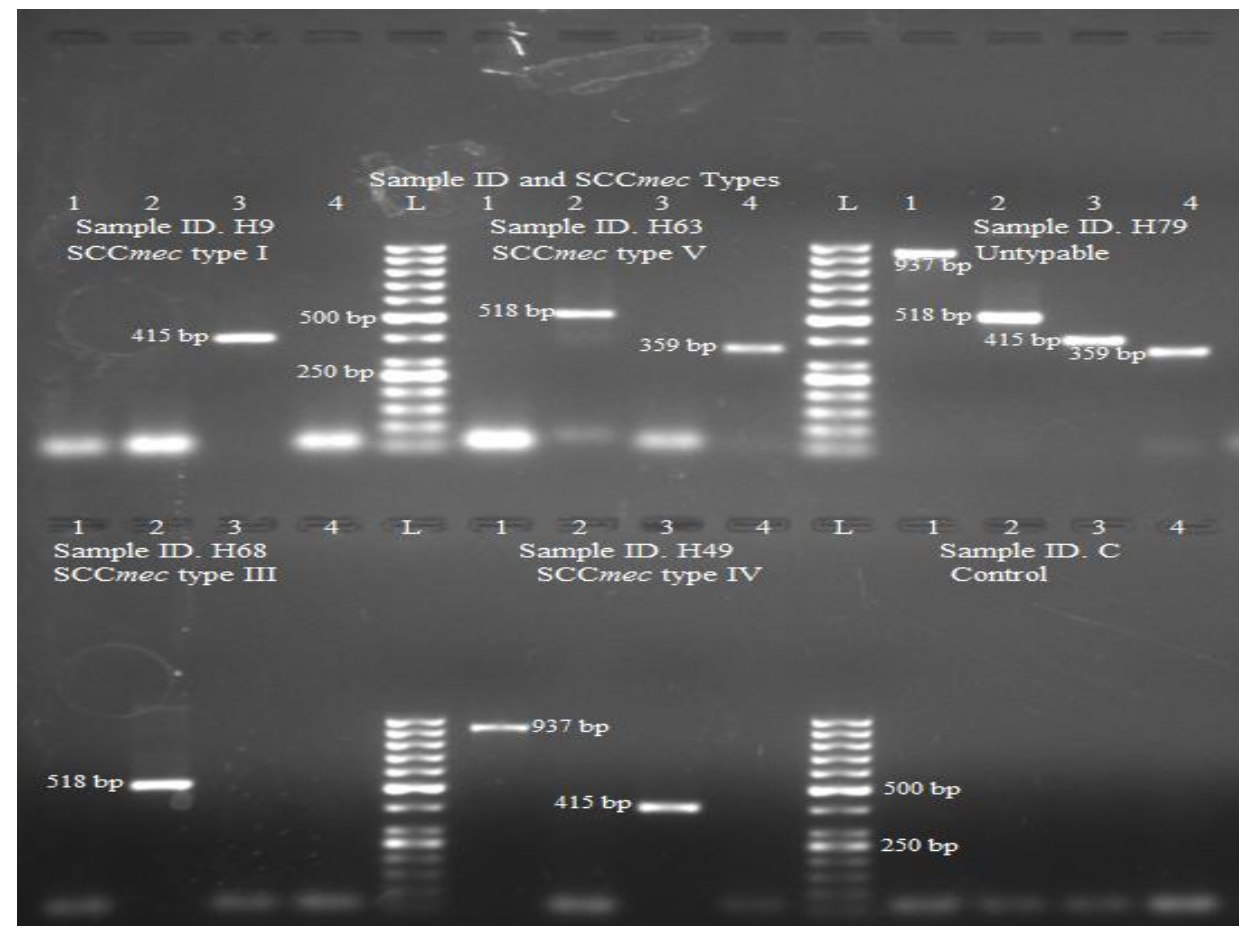

Similarly, study revealed $25 \%$ (10/40) isolates were classified as hospital associated methicillin resistant staphylococci (HA-MRS) (SCCmec type I, 7; SCCmec type III, 3), whereas $45 \%$ (18/40) isolates were classified as community associated methicillin resistant staphylococci (CA-MRS) (SCCmec type IV, 9; SCCmec type V, 9) isolates and 30\% (12/40) isolates remained untypable from human MRS isolates. The overall percentage of CA-MRS (63.04\%) was higher as compare to HA-MRS (28.26\%) among both the species (Figure 2).

In many countries, the presence of MRSA in animal and human is of veterinary and public health concern. Nasal carriage has an important role in the epidemiology and pathogenesis of MRSA infection in human and animal (Kluytmans et al., 1997). Several reports showed the prevalence of MRSA in cattle with mastitis (Bhagat et al., 2017). In a study made in farm animals, the nasal MRSA prevalence was found to be $0.3 \%$ and $1 \%$ in 400 cattle and 300 calves, respectively (Huber et al., 2010) which was lower as compared to present findings. In comparison to current finding, higher rates of MRSA were reported by, Erdem and Turkyilmaz (Erdem and Turkyilmaz, 2013) reported $7.14 \%$ (4/56) bovine and $17.64 \%$ (6/34) human nasal isolates were positive for MRSA. In another study from Turkey, Methicillin resistant was detected in $26.8 \%(15 / 56)$ and $62.8 \%$ (22/35) of bovine nasal and human nasal isolates, respectively (Inegol and Turkyilmaz, 2012). Garipcin and Seker, (Garipcin and Seker, 2015) revealed the nasal carriage rates of MRSA in 150 humans and 250 cattle at the rate of $8.7 \%$ and $1.2 \%$ respectively.

Amplification of all these primers in accordance with presence of respective genes gives identification of presence of Methicillin-resistant Coagulase Negative Staphylococci (MRCoNS) or Methicillin- 
Resistant Coagulase Positive Staphylococci (MRCoPS). Similar to present study Nimavat, (Nimavat, 2015) and Hetal, (Hetal, 2016) applied multiplex PCR assay using same primer pairs used in this study and characterized the staphylococci as similar fashion as characterized in this study.

The study revealed higher percentage of CAMRSA isolates as compare to HA-MRSA in animal as well as in human, indicating emergence of CA-MRSA strains in this geographical area. Inegol and Turkyilmaz (Inegol and Turkyilmaz, 2012) revealed higher rate of $(67.80 \%)$ isolates including type II and III were hospital acquired (HAMRS) whereas $32.20 \%$ isolates including type IV and $\mathrm{V}$ were community acquired (CAMRS), which was lower as compared to present finding, but they had reported similarity of SCCmec types between bovine and human isolates, suggestive of evidence of transmission from animals to humans, or vice versa. Bhutia et al., (Bhutia et al., 2015) reported $25.33 \%(38 / 150)$ isolates met the definition of CA-MRSA and 10\% (15/150) of HA-MRSA, which was lower as compare to present study.

During the study, the isolates from animal (Milk, pus/exudate) yielded various SCCmec type (SCCmec type I, III, IV and V), similarly the same SCCmec types were isolated from the human nasal swab of labors/worker/personnel who remain in close contact with this animals. During the current study, the same SCCmec types prevail in animaland human beings attributed the transmission of MRS from animal to human or vice versa indicating potential zoonotic pathogen prevalence in farm animal and their workers.

Simultaneously, we found that the MRSA strains harboured the high and variable prevalence of SCCmec alleles which is an additional pathogenic factor for infections. SCCmec IV and V were the most prevalent alleles in our findings. The CA-MRSA is mainly considered by SCCmec IV and V alleles, while HA-MRSA are recognized by SCCmec I, II and III alleles (De Lencastre, 2007). During the current study, MRS strains were mainly associated with CA-MRSA. In other hand, detection of SCCmec types IV and $\mathrm{V}$ suggested the emergence of CA-MRSA strains in this geographical area and occurrence of SCCmec I and II alleles indicated a possible transmission of MRSA from humans to animals. Further studies are needed to establish clonal relation of MRS from animaland farm workers with advance molecular techniques (Pulsed field gel electrophoresis, Staphylococcal Protein A analysis, multilocus sequence typing). The result of these studies may shed light on the clonility and transmission of resistance strain between human and animal. High prevalence of SCCmec types IV and V were also detected by various authors (Havaei et al., 2015).

MRSA infected cattle acts as a reservoir and later transmit the infections to other animals and humans. MRSA colonization in cattle may be an occupational risk to the people in close contact with MRSA infected cattle such as veterinarians, farmers, milkers and people working at slaughterhouses. Transmission of animal MRSA to veterinary personnel has been found and it is more common for large animal personnel than small animal personnel (Wulf et al., 2008).

Although, MRSA has been reported as transmissible diseases of zoonosis as well as humanosis importance, the direction and routes of transmission are superficially understood. Some authors have reported bidirectional transmission of MRSA (Ferreira et al., 2011). Animal to human transmission occurs through direct contact, environmental contamination and through handling of 
infected animal product, whereas human to animal transmission is still unclear (Weese, 2010).

The similar SCCmec types in both the groups (Animal and human) suggest co-circulation of MRS isolates between human and animal population which was indication of possible lateral gene transfer between the staphylococcal isolates in this region. Most of the reported SCCmec types (except SCCmec type II) were found in this region. Higher number of CA-MRS associated types IV, V and a marked number of these in animal isolates suggested the possible transfer of resistance from human to animal isolates.

\section{References}

American Veterinary Medical Association (AVMA). 2014. MRSA and animals FAQ. Available online at https://www.avma.org/KB/Resources/F AQs/Pages/MRS A-HHP-FAQs.aspx.

Bhagat, A. G., H.N. Kher, A.I. Dadawala, H.C. Chauhan, B.K. Patel, M.D. Shrimali and B. S. Chandel. 2017. Identification and characterization of Methicillin-resistant Staphylococcus aureus isolated from bovine mastitis. Int. J. Curr. Microbiol. App. Sci, 6(2): 223-230.

Bhutia, K. O., Singh, T. S. K., Adhikari, L. and Biswas, S. 2015. Molecular characterization of community- \& hospital-acquired methicillin-resistant \& methicillin-sensitive Staphylococcus aureus isolates in Sikkim. Indian J. Med. Res, 142: 330-335.

Boye, K., Bartels, M. D., Andersen, I. S., Moller, J. A. and Westh. H. 2007. A new multiplex PCR for easy screening of methicillin-resistant Staphylococcus aureus SCCmec types I-V. Clin. Microbiol. Infect, 13: 725-727.

Brakstad, O. G. Aasbakk, K and Maeland, J.
A. 1992. Detection of Staphylococcus aureus by polymerase chain reaction amplification of the nuc gene. J. Clin. Microbiol, 30(7):1654-1660.

Chambers, H. F. and Deleo, F. R. 2009. Waves of resistance: Staphylococcus aureus in the antibiotic era. Nat Rev Microbiol, 7: 629-641.

De Lencastre, H., Oliveira, D. and Tomasz, A. 2007. Antibiotic resistant Staphylococcus aureus: A paradigm of adaptive power. Curr. Opin. Microbiol, 13: 971-979.

Erdem, Z. and Turkyilmaz, S. 2013. Molecular typing of methicillin resistant Staphylococcus aureus strains isolated from cows and farm workers. Kafkas Univ. Vet. Fak. Derg, 19: 963-968.

European Food Safety Authority (EFSA). 2009. Assessment of the Public Health significance of methicillin resistant Staphylococcus aureus (MRSA) in animals and foods. Scientific Opinion of the Panel on Biological Hazards. EFSAJ,93:1-73.

Garipcin, M. and Seker, E. 2015. Nasal carriage of methicillin-resistant Staphylococcus aureus in cattle and farm workers in Turkey. Vet. Arhiv, 85:117-129.

Havaei, S. A., Assadbeigi, B., Esfahani, B. N., Hoseini, N. S., Rezaei, N. and Havaei, S. R. 2015. Detection of mecA and enterotoxin genes in Staphylococcus aureus isolates associated with bovine mastitis and characterization of Staphylococcal cassette chromosome mec (SCCmec) in MRSA strains. Iranian journal of microbiology, 3: 161-167.

Hetal, J. 2016. Optimization of real time PCR for detection of methicillin resistant staphylococci and molecular characterization of mecA gene. M. V. Sc. (Veterinary Microbiology) Thesis (Unpublished). Junagadh Agricultural 
University, Junagadh.

Huber, H., Koller, S., Giezendanner, N., Stephan, R. and Zweifel, C. 2010.Prevalence and characteristics of methicillin-resistant Staphylococcus aureus in humans in contact with farm animals, in livestock, and in food of animal origin, Switzerland. Euro Surveill, 15(16): 19542.

Inegol, E. and S. Turkyilmaz, S. 2012. Determination of SCCmec types in methicillin resistant Staphylococci isolated from cows and farm workers. Ankara Univ. Vet. Fak. Derg,59: 89-93.

Ito, T., Katayama, Y., Asada, K., Mori, N., Tsutsumimoto, K., Tiensasitorn, C. and Hiramatsu. K. 2001. Structural comparison of three types of staphylococcal cassette chromosome mec integrated in the chromosome in methicillin-resistant Staphylococcus aureus. Antimicrob. Agents Chemother, 45: 1323-1336.

Ito, T., Ma, X. X., Takeuchi, F., Okuma, K., Yuzawa, H. and Hiramatsu, K. 2004. Novel type V staphylococcal cassette chromosome mec driven by a novel cassette chromosome recombinase, ccrC. Antimicrob. Agents Chemother, 48: 2637-2651.

Jakee, J. K., Aref, N. E., Gomaa, A., Hariri, M. D., Galal, H. M., Omar, S.A. and Samir, A. 2013. Emerging of coagulase negative staphylococci as a cause of mastitis in dairy animals: An environmental hazard. Int. J. Vet. Sci. Med, 1: 74-78.

Kluytmans, J., Belkum, A. V. And Verbrugh, H. 1997. Nasal carriage of Staphylococcus aureus: epidemiology, underlying mechanisms, and associated risks. Clin. Microbiol. Rev, 10: 505520.

Malik, S., Peng, H. and Barton, M. 2006. Partial nucleotide sequencing of the mecA genes of Staphylococcus aureus isolates from dogs and cats. J. Clin. Microbiol, 44: 413-416.

Martineau, F., Picard, F. J., Ke, D., Paradis, S., Roy, P. H., Ouellette, M. and Bergeron, M.G. 2001. Development of a PCR assay for identification of staphylococci at genus and species levels. J. Clin. Microbiol, 39:25412547.

Moon, J. S., Lee, A. R., Kang, H. M., Lee, E. S., Joo, Y. S., Park, Y. H., Kim, M. N. and Koo, H. C. 2007. Antibiogram and coagulase diversity in staphylococcal enterotoxin-producing Staphylococcus aureus from bovine mastitis. J. Dairy Sci, 90: 1716-1724.

Naimi, T. S., LeDell, K. H., Como-Sabetti, K., Borchardt, S. M., Boxrud, D. J., Etienne, J., Johnson, S. K., Vandenesch, F. and Fridkin, S. 2003. Comparison of community- and health care associated methicillin-resistant Staphylococcus aureus infection. JAMA, 290: 29762984.

Nimavat, V. R. 2015. Optimization of multiplex PCR for identification of MRSA from bovine milk samples \& its comparison with conventional diagnostic methods. M. V. Sc. (Veterinary) Thesis (Unpublished). Junagadh Agricultural University, Junagadh.

Parayre S., Falentin H., Madec M. N., Sivieri K., Le Dizes A. S., Sohier D. andLortal S. 2007. DNA extraction method and optimization of PCR-temporal temperature gel electrophoresis to identify the predominant high and low GC-content bacteria from dairy products. J. Microbiol. Methods, 69:431-441.

Peacock, S. J., de Silva I. and Lowy F. D. 2001. What determines nasal carriage of Staphylococcus aureus? Trends Microbiol, 9 (12): 605-610.

Quinn, P. J., Carter, M. E., Markey, B. K. and 
Carter, G. R. 1994. Enterobacteriaceae. In: Quinn, P. J.; Carter, M. E.; Markey, B. K. and Carter, G. R. (eds) Clinical Veterinary Microbiology. Mosby-Year Book Europe, London, pp. 209-236

Shore, A. Rossney, A. S. Keane, C. T. Enright, M. C. and Coleman, D. C. 2005. Seven novel variants of the staphylococcal chromosomal cassette mec in methicillin-resistant Staphylococcus aureus isolates from Ireland. Antimicrob. Agents Chemother, 49: 2070-2083.

Weese, J. S. 2010. Methicillin-Resistant Staphylococcus aureus in Animals. ILARJ, 51: 233-244.

Wulf, M. W., Sorum, M., VanNes, A., Skov,
R., Melchers, W. J. and Klaassen, C. H. and Voss, A. 2008. Prevalence of methicillin-resistant Staphylococcus aureus among veterinarians: an international study. Clin. Microbiol. Infect, 14(1): 29-34.

Zhang, K. McClure, J. A. Elsayed, S. and Conly, J. M. 2009. Novel staphylococcal cassette chromosome mec type, tentatively designated type VIII, harboring class Amec and type 4 ccr gene complexes in a Canadian epidemic strain of methicillin-resistant Staphylococcus aureus. Antimicrob. Agents Chemother, 53: 531-540.

\section{How to cite this article:}

Ghodasara, S.N., J.H. Purohit, A.R. Baria, A.S. Patel, B.B. Javia, D.B. Barad, J.A. Kathiria and Bhadania, A.R. 2019. Molecular Characterization of Major Types of Staphylococcal Cassette Chromosomemec (SCCmec) in Methicillin-Resistant Staphylococci (MRS) from Animal and Human Origin. Int.J.Curr.Microbiol.App.Sci. 8(10): 916-927. doi: https://doi.org/10.20546/ijcmas.2019.810.107 